\title{
DESAFIOS À CONCRETIZAÇÃO DA TRANSPARÊNCIA ATIVA NA INTERNET, À LUZ DA LEI DE ACESSO À INFORMAÇÃO PÚBLICA: análise dos portais dos Tribunais Regionais Federais
}

\author{
CHALLENGES TO IMPLEMENTATION OF ACTIVE TRANSPARENCY IN \\ INTERNET, IN THE LIGHT OF THE LAW OF PUBLIC ACCESS TO \\ INFORMATION: analysis of the portals of the Federal Regional Courts
}

\begin{abstract}
PATRÍCIA ADRIANI HOCH
Acadêmica do Curso de Direito da Universidade Federal de Santa Maria (UFSM). Integrante do Núcleo de Direito Informacional (NUDI).
\end{abstract}

LUCAS MARTINS RIGUI Graduado em Direito pela Universidade Federal de Santa Maria (UFSM). Integrante do Núcleo de Direito Informacional (NUDI).

Rosane LeAL da SiLva Doutora em Direito pela Universidade Federal de Santa Catarina (UFSC). Professora Adjunta do Curso de Direito da Universidade Federal de Santa Maria (UFSM). Coordenadora do Núcleo de Direito Informacional (NUDI).

\section{RESUMO}

A Lei $n^{\circ} 12.557$ regulamentou o direito fundamental à informação, estabelecendo como regra a transparência pública. Por meio do método de abordagem dedutivo, partiu-se do direito ao acesso à informação e do dever de transparência ativa pelo Poder Público, com destaque para o uso das Tecnologias da Informação e Comunicação, especialmente a Internet, salientando-se as inovações legais. A pesquisa bibliográfica e documental é complementada pelo emprego do método de procedimento monográfico ou de estudo de casos, a partir do qual foram eleitos e observados, de maneira sistemática e não-participativa, os portais dos Tribunais Regionais Federais, a fim de se verificar quais são os desafios à concretização da transparência ativa. Constatou-se que há deficiências no cumprimento da Lei $n^{\circ} 12.557 / 11$ e que o desenvolvimento da cultura de acesso, pautada pela uniformização, usabilidade e interoperabilidade da informação são desafios que devem ser superados.

Palavras-chave: Sociedade informacional. Internet. Lei de Acesso à Informação Pública. Direitos fundamentais.

\begin{abstract}
The Law $N^{\circ}$. 12.557 regulates the fundamental right to information, establishing, as a rule, the public transparency. Through the method of deductive approach, we started with the right to access to information and active transparency duty by the Government, especially the use of Information Technology and Communication, mainly the Internet, highlighting the legal innovations. The bibliographic and documentary research is complemented using the monographic procedure method or study of cases, from which were elected and observed systematically and non-participatory, the portals of the federal courts, in order to ascertain which are the challenges to achieving active transparency. It was found that there are deficiencies in the fulfillment of Law No. $12.557 / 11$ and that the development of a access culture, guided by standardization, interoperability and usability of information are challenges that must be overcome.
\end{abstract}

Keywords: Informational society. Internet. Law of Access to Public Information. Fundamental rights. 


\section{SUMÁRIO}

INTRODUÇÃO; 10 DEVER DE TRANSPARÊNCIA ATIVA DO ESTADO: a importância das Tecnologias de Informação e Comunicação para a aplicação da Lei de Acesso a Informação; 2 DESAFIOS À EFETIVAÇÃO DA TRANSPARÊNCIA ATIVA, NOS TERMOS DA LEI N 12.527/11: uma análise dos portais dos Tribunais Regionais Federais; CONCLUSÃO; REFERÊNCIAS.

\section{INTRODUÇÃO}

O direito fundamental ao acesso à informação foi previsto no artigo $5^{\circ}$, XXXIII da Constituição Federal de 1988. Após uma evolução histórica, a partir da qual os Estados não só perderam o monopólio das informações que chegam aos cidadãos, como passaram a ser demandados para promover a transparência, tanto ativa, como passiva, foi promulgada no Brasil a Lei de Acesso à Informação, $n^{\circ}$ 12.557, em 18 de novembro de 2011, a fim de regulamentar a previsão constitucional.

Com o advento dessa legislação, foi instaurada no cenário brasileiro uma mudança de paradigma, tendo em vista que o desenvolvimento da cultura de acesso, ancorada na publicidade e na transparência, constitui-se como regra, e o sigilo, como exceção. Nesse contexto, a utilização das Tecnologias de Informação e de Comunicação (TIC's), com destaque para a Internet, representa uma alternativa eficaz na comunicação e interação com a sociedade, de forma que, um efetivo acesso à informação representará um importante marco para o controle social e participação cidadã.

Para tanto, é necessário que a Lei de Acesso à Informação, que prevê a máxima divulgação de dados por todos os órgãos e esferas do Poder Público, seja aplicada na sua integralidade. Nesse contexto, o presente estudo, produzido como resultado parcial do Projeto de Pesquisa intitulado "O uso das tecnologias da informação e comunicação pelo Poder Judiciário brasileiro: os sites e portais como instrumentos para implementar a Lei $n^{\circ}$ 12.527/11", que visa abordar quais são os desafios para que a transparência ativa seja efetivamente implementada no Brasil.

Com essa finalidade, empregou-se o método de procedimento monográfico, a partir do qual foram selecionados os sites e portais dos Tribunais Regionais Federais que integram o Poder Judiciário, considerados mais relevantes para os limites deste trabalho. Uma vez feita a seleção, empregou-se a técnica de observação direta, sistemática e não-participativa, com o objetivo de 
verificar se tais portais governamentais estão adequados às exigências da Lei $\mathrm{n}^{\circ}$ 12.527/11, destacando-se quais são as deficiências apresentadas que inviabilizam ou dificultam o acesso à informação e, consequentemente, a transparência ativa.

Partindo dessa base metodológica, dividiu-se o artigo em duas partes: num primeiro momento enfrenta-se o direito fundamental ao acesso à informação, abordando-se aspectos relevantes trazidos pela Lei $\mathrm{n}^{\circ} 12.527 / 11$, com ênfase no dever de transparência ativa (decorrente do princípio da publicidade), por meio do uso das TIC'S. A segunda parte do trabalho, por sua vez, destina-se a verificar a estrutura dos sites e portais dos tribunais referidos, com o escopo de observar quais são os desafios ao Estado Brasileiro para a efetivação da transparência ativa, à luz das disposições da Lei de Acesso à Informação.

\section{DEVER DE TRANSPARÊNCIA ATIVA DO ESTADO: a importância das Tecnologias de Informação e Comunicação para a aplicação da Lei de Acesso à Informação Pública}

A informação é o pilar das relações sociais, sendo conceituada por Maria Eduarda Gonçalves ${ }^{1}$ como:

[...] um estado de consciência sobre factos ou dados; o que quer dizer que pressupõe um esforço (de carácter intelectual, antes de mais) que permita passar da informação imanente (dos factos ou dados brutos) à sua percepção e entendimento, o que implica, normalmente, a sua recolha, tratamento e organização.

A Autora destaca que devido ao desenvolvimento do computador, que permite o armazenamento de uma gama de dados e registros, a informação passou a ter um papel central nas atividades humanas e sociais. A partir disso, salienta que na sociedade da informação, marcada pelo uso das novas tecnologias, é “possível organizar e apresentar sob formatos diversos uma maior quantidade e diversidade de dados e/ou conhecimentos"2.

O conhecimento e consciência sobre fatos e dados tratado pela Autora, perpassa a necessidade de que haja acesso à informação, o qual foi elencado como fundamental na

\footnotetext{
${ }^{1}$ GONÇALVES, Maria Eduarda. Direito da Informação: novos direitos e formas de regulação na Sociedade da Informação. Almedina: Coimbra, 2003, p. 17.

${ }^{2}$ Ibidem, p. 18.

REDESG / Revista Direitos Emergentes na Sociedade Global - www.ufsm.br/redesg v. 1, n. 2, jul.dez/2012 Revista do Programa de Pós-graduação em DiReITO da Universidade Federal de SANTA MARIA - www.ufsm.br/ppgd
} 
DESAFIOS À CONCRETIZAÇÃO DA TRANSPARÊNCIA ATIVA NA INTERNET, À LUZ DA LEI DE ACESSO À INFORMAÇÃO PÚBLICA: análise dos portais dos Tribunais Regionais Federais

Constituição Federal de 1988, no artigo 5 $5^{\circ}$ inciso XXXIII ${ }^{3}$. Ao longo dos anos, principalmente no período pós-guerra, diversos Tratados e Convenções foram realizados pela comunidade internacional e assinados pelo Brasil. Dentre eles, destaca-se a Declaração de Atlanta ${ }^{4}$, oriunda da Conferência Internacional em Atlanta, na Geórgia (EUA), realizada em 29 de fevereiro de 2008.

0 referido Documento enumerou regras, princípios, premissas básicas e palavras-chave destinadas a efetivar o acesso à informação, por meio da transparência, destacando, inclusive, o uso das novas tecnologias no sentido da facilitação do acesso. Além disso, enalteceu a importância da conscientização pública, de modo que o cidadão tenha a capacidade de exercer o direito fundamental de acesso à informação, reconhecido, à época, com status de autônomo e universal.

Considerando a importância da máxima divulgação ${ }^{5}$, a regulamentação do direito fundamental à informação previsto no artigo $5^{\circ}$, bem como do disposto nos artigos $37^{6}$, § $3^{\circ}$, II3 e $216^{7}, \S 2^{\circ}$, do mesmo diploma legal, ocorreu com a promulgação da Lei de Acesso à Informação, $n^{\circ}$ 12.527, em 18 de novembro de 2011, a qual entrou em vigor em 16 de maio de 2012. Primeiramente, a informação deve ser entendida num sentido amplo, abrangendo, segundo o

\footnotetext{
${ }^{3}$ Art. $5^{\circ}$, inciso XXXIII: Todos têm direito a receber dos órgãos públicos informações de seu interesse particular, ou de interesse coletivo ou geral, que serão prestadas no prazo da lei, sob pena de responsabilidade, ressalvadas aquelas cujo sigilo seja imprescindível à segurança da sociedade e do Estado. BRASIL. Constituição da República Federativa do Brasil de 1988. Brasília: Senado Federal, 1988. Disponível em: < <http://www.planalto.gov.br/ccivil_03/constituicao/constitui\%C3\%A7ao.htm>. Acesso em: 08 nov. 2012.

${ }^{4}$ INTERNACIONAL CONFERENCE ON THE RIGHT PUBLIC INFORMATION. February, 27-29, 2008. Declaração de Atlanta e plano de ação para o avanço do direito de acesso à informação. Disponível em: <http://www.cartercenter.org/resources/pdfs/peace/americas/atlanta_declaration_unofficial_portugues e.pdf>. Acesso em 08 nov. 2012.

${ }^{5} \mathrm{O}$ princípio de máxima divulgação estabelece a premissa de que toda a informação mantida por organismos públicos deve estar sujeita à divulgação e de que tal suposição só deverá ser superada em circunstâncias muito limitadas. Acesso à informação e controle social das políticas públicas; coordenado por Guilherme Canela e Solano Nacimento. Brasília, DF: ANDI, ARTIGO 19, 2009, p.21.

${ }^{6}$ Artigo 37 - A administração pública direta e indireta de qualquer dos Poderes da União, dos Estados, do Distrito Federal e dos Municípios obedecerá aos princípios de legalidade, impessoalidade, moralidade, publicidade e eficiência [...]. § $3^{\circ}$ - A lei disciplinará as formas de participação do usuário na administração pública direta e indireta, regulando especialmente: II - o acesso dos usuários a registros administrativos e a informações sobre atos de governo. Brasil, op. cit.

7 Artigo 216 - [...] $\$ 2^{\circ}$ Cabem à administração pública, na forma da lei, a gestão da documentação governamental e as providências para franquear sua consulta a quantos dela necessitem. Brasil, op. cit. REDESG / Revista Direitos Emergentes na Sociedade Global - www.ufsm.br/redesg v. 1, n. 2, jul.dez/2012 Revista do Programa de Pós-graduaÇão em Direito da Universidade Federal de Santa Maria - www.ufsm.br/ppgd
} 
artigo $4^{\circ}$, I, “dados, processados ou não, que podem ser utilizados para produção e transmissão de conhecimento, contidos em qualquer meio, suporte ou formato" ${ }^{\text {. }}$

Visando assegurar o direito fundamental de acesso à informação, a Lei $n^{\circ} 12.527 / 11$ traz em seu artigo $3^{\circ}$, importantes diretrizes, quais sejam: I) observância da publicidade como preceito geral e do sigilo como exceção; II) divulgação de informações de interesse público, independentemente de solicitações; III) utilização de meios de comunicação viabilizados pela tecnologia da informação; IV) fomento ao desenvolvimento da cultura de transparência na administração pública e V) desenvolvimento do controle social da administração pública. Tais premissas, contempladas pela Lei de Acesso à Informação, que guiarão o Estado Brasileiro no caminho da efetivação desse direito fundamental, serão analisadas suscintamente no presente trabalho?.

A primeira diretriz supramencionada instaurou uma mudança de paradigma no cenário brasileiro, de modo que a regra é a publicização, com o desenvolvimento da cultura de acesso. 0 sigilo, por sua vez, somente ocorre nas hipóteses previstas na lei, sendo, portanto, a exceção. Por ser admitido somente na excepcionalidade, o sigilo visa proteger dois eixos, quais sejam: “individual, no tocante à honra, imagem, intimidade e vida privada das pessoas; e público, quando o sigilo se revele necessário ou conveniente à segurança e à integridade do Estado ou da sociedade" 10 , hipótese em que a restrição de acesso público será apenas temporária, conforme artigo $4^{\circ}$, III, da legislação ${ }^{11}$.

Desta feita, somente nos casos previstos na lei, pode haver restrição do acesso à informação, sendo que, não se pode negar o acesso quanto esta é "necessária à tutela judicial ou administrativa de direitos fundamentais", bem como quando verse "sobre condutas que

\footnotetext{
${ }^{8}$ BRASIL. Lei $\mathrm{n}^{\circ} \mathbf{1 2 . 5 2 7}$, de 18 de novembro de 2011. Regula o acesso a informações previsto no inciso XXXIII do art. 5o, no inciso II do § 30 do art. 37 e no § 20 do art. 216 da Constituição Federal; altera a Lei no 8.112, de 11 de dezembro de 1990; revoga a Lei no 11.111, de 5 de maio de 2005, e dispositivos da Lei no 8.159, de 8 de janeiro de 1991; e dá outras providências. Disponível em: <http://www.planalto.gov.br/ccivil_03/_ato2011-2014/2011/lei//12527.htm>. Acesso em 08 nov. 2012. ${ }^{9}$ Ibidem.

${ }^{10}$ MIRAGEM, Bruno. A Nova Administração Pública e o Direito Administrativo. São Paulo: Editora Revista dos Tribunais, 2011, p. 325.

${ }^{11}$ BRASIL. Lei $\mathrm{n}^{\circ} 12.527$, de 18 de novembro de 2011. Regula o acesso a informações previsto no inciso XXXIII do art. 5o, no inciso II do § 30 do art. 37 e no § 20 do art. 216 da Constituição Federal; altera a Lei no 8.112, de 11 de dezembro de 1990; revoga a Lei no 11.111, de 5 de maio de 2005, e dispositivos da Lei no 8.159, de 8 de janeiro de 1991; e dá outras providências. Disponível em:

<http://www.planalto.gov.br/ccivil_03/_ato2011-2014/2011/lei//12527.htm>. Acesso em 08 nov. 2012. REDESG / Revista Direitos Emergentes na Sociedade Global - www.ufsm.br/redesg v. 1, n. 2, jul.dez/2012 Revista do Programa de Pós-gRaduaÇão EM DIREITO da UnIVERSIDAde Federal de SANTA MARIA - www.ufsm.br/ppgd
} 
impliquem violação dos direitos humanos praticada por agentes públicos ou a mando de autoridades públicas não poderão ser objeto de restrição de acesso"12.

Nesse aspecto, a informação sigilosa pode ser classificada em: a) ultrassecreta, com prazo máximo de restrição de 25 (vinte e cinco) anos; b) secreta, com prazo de 15 (quinze) anos e, por fim, c) reservada, pelo prazo de 5 (cinco) anos, conforme artigo 24 , § $1^{\circ}$. Transcorridos tais períodos, a informação se torna, automaticamente, acessível ao público. Importante ressaltar que essa classificação deve observar o interesse público, com a utilização do critério menos restritivo possível, levando em consideração a gravidade do riscou ou dano à segurança da sociedade e do Estado; e o prazo máximo de restrição de acesso ou o evento que defina seu termo final.

A partir disso, a recusa no fornecimento da informação deve ser justificada, caso o Poder Público demonstre que a limitação atende ao chamado "teste de três fases", elaborado pela jurisprudência internacional, o qual possui o "objetivo avaliar, em cada caso concreto, a relação custo (dano) / benefício (interesse público) na divulgação de uma dada informação”13. 0 teste de três princípios estabelece que: “1) a informação deve relacionar-se com um dos objetivos legítimos listados na lei; 2 ) a divulgação deverá ameaçar causar graves prejuízos a tal objetivo; 3) o prejuízo ao objetivo em questão deve ser maior que o interesse público à informação específica"14. Por privilegiar o acesso amplo, em detrimento do segredo, esse teste se mostra adequado no sentido de atender aos anseios desse novo modelo.

Sob os aspectos constitucional e administrativo, Bruno Miragem ${ }^{15}$ vincula a transparência ao princípio da publicidade, previsto no artigo 37 da Carta Magna, sustentando que este "é o fundamento principal da adoção de políticas de transparência no âmbito da Administração Pública”. Nesse contexto, destaca que:

A noção de publicidade da ação administrativa, neste aspecto, resulta em um dever de transparência na exata medica em que estabelece como paradigma da ação administrativa sua exposição ao conhecimento público, para acesso de

\footnotetext{
12 Ibidem.

13 Acesso à informação e controle social das políticas públicas; coordenado por Guilherme Canela e Solano Nacimento. Brasília, DF: ANDI, ARTIGO 19, 2009, p.22.

${ }^{14}$ ARTIGO 19. O direito do público a estar informado. Princípios sobre a legislação de liberdade de informação. $\quad$ Artigo 19: Londres, $1999 . \quad 0 \quad$ Disponível em: <http://www.article19.org/data/files/pdfs/standards/public-right-to-know-portuguese.pdf>. Acesso em 09 nov. 2012.

${ }^{15}$ MIRAGEM, Bruno. A Nova Administração Pública e o Direito Administrativo. São Paulo: Editora Revista dos Tribunais, 2011, p. 308/309.

REDESG / Revista Direitos Emergentes na Sociedade Global - www.ufsm.br/redesg v. 1, n. 2, jul.dez/2012 Revista do Programa de Pós-graduaçÃo em DiREITO dA Universidade FEderal de SANTA MARIA - www.ufsm.br/ppgd
} 
qualquer interessado, como condição, critério para sua legitimidade. 0 dever de transparência que resulta desta eficácia do princípio da publicidade abrange tanto os processos de decisão da Administração, quanto informações públicas de um modo geral, refletindo a ação transparente do agente público e promovendo o uso público da razão nos assuntos de interesse geral da comunidade, sob o patrocínio ou com a participação do Estado ${ }^{16}$.

Segundo o Autor, na Administração Pública o dever de transparência ocorre não somente por meio da promoção e divulgação de informações públicas, "assim também como dever de abstenção que the é lógica e imediatamente correlato, de não se comportar de modo a impedir ou dificultar o acesso de qualquer cidadão a informações públicas”. Nesse aspecto, conforme afirmado por Patrícia Peck Pinheiro ${ }^{17}$, dependendo do sujeito de direito, o direito à informação abrange três categorias, quais sejam o “1) direito de informar, que é um direito ativo; 2) direito de ser informado, que é um direito passivo; 3) o direito de não receber informação, que é um direito ativo e passivo".

A transparência, por sua vez, se divide em ativa, a qual consiste na divulgação espontânea de informações, e passiva, por meio da qual o Poder Público é provocado mediante requerimento do interessado, conforme explica Paula Lígia Martins ${ }^{18}$ :

O direito de acesso à informação impõe duas obrigações sobre os governos. Primeiro, existe a obrigação de publicar e disseminar informações essenciais sobre o que os diferentes órgãos públicos estão fazendo. Segundo, os governos têm a obrigação de receber do público pedidos de informação e respondê-los, disponibilizando os dados solicitados e permitindo que o público tenha acesso aos documentos originais indicados ou receba cópias dos mesmos.

Partindo do pressuposto de que "os órgãos públicos não detêm informações eles próprios, mas atuam como guardiães do bem público" ${ }^{19}$, ao estabelecer a divulgação espontânea de informações de interesse geral ou coletivo, a segunda diretriz, trazida pelo artigo $3^{\circ}$, trata da transparência ativa do Estado, objeto do presente estudo, visto que:

Como contraponto ao segredo, a noção de publicidade passa pela perspectiva de se garantir um Estado transparente, cujas ações e motivações estariam expostas à vigilância dos cidadãos, expostas aos olhos do público. Algo distinto do Estado

\footnotetext{
16 Ibidem.

17 PINHEIRO, Patrícia Peck. Direito Digital. 4 ed. rev., atual. e ampl. São Paulo: Saraiva, 2010, p. 83.

18 MARTINS, Paula Lígia. Acesso à informação: Um direito fundamental e instrumental. Acervo: Rio de Janeiro, 2011, p. 2.

${ }_{19}$ MENDEL, Toby. Liberdade de informação: um estudo de direito comparado. 2.ed. Brasilia: UNESCO, 2009, p. 4.

REDESG / Revista Direitos Emergentes na Sociedade Global - www.ufsm.br/redesg v. 1, n. 2, jul.dez/2012

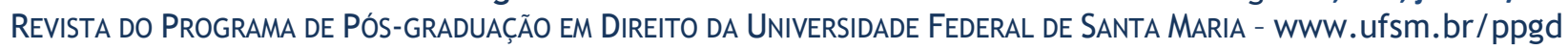


autocrático, que tende a se apoiar no segredo para existir e melhor gerenciar o poder concentrado ${ }^{20}$.

A credibilidade das instituições públicas é pautada na transparência da gestão, aliada a outros instrumentos que reforcem o direito e a possibilidade real de fiscalização da máquina pública, tendo em vista que governos fechados excluem a sociedade do cenário político ${ }^{21}$. Nesse contexto, no Estado Democrático Brasileiro, merece ênfase a adoção de uma postura proativa, baseada no "governo aberto", o qual segundo a organização não-governamental ARTIGO 19, consiste em "informar o público sobre os seus direitos e promover uma cultura de abertura no seio do governo, são aspectos essenciais para que a finalidade da legislação sobre a liberdade de informação seja alcançada"22.

Anteriormente à publicação da norma ora em análise, em 2011, o Brasil, primando pela Transparência ativa, assinou junto à comunidade internacional a "Declaração de Governo Aberto"23, a qual visa, primordialmente, tornar os governos mais transparentes, receptivos, responsáveis e eficientes, objetivando "promover a transparência, lutar contra a corrupção, dar poder aos cidadãos e dominar o poder das novas tecnologias para tornar o governo mais efetivo e responsável".

Além disso, o mencionado Documento pretende aumentar a disponibilidade de informações relacionadas às atividades governamentais, firmando o compromisso de intensificar os "esforços de coletar e publicar sistematicamente dados sobre os gastos e o desempenho governamentais relativos a serviços e atividades essenciais", bem como de "fornecer informações valiosas de maneira proativa, entre as quais dados básicos, de forma oportuna, em formatos fáceis de localizar, compreender e utilizar, e que facilitem a reutilização"24.

Há menção também à busca pelo acesso da sociedade às informações e na facilitação da interoperabilidade dos sistemas de informação, tendo em vista que "as novas tecnologias

\footnotetext{
${ }^{20}$ Internet e participação política no Brasil. Orgs. Rousiley Celi Moreira Maria, Wilson Gomes, Francisco Paulo Jamil Almeida Marques. Poro Alegre; Sulina, 2011, p. 126.

${ }^{21}$ MARTINS, Paula Lígia. Acesso à informação: Um direito fundamental e instrumental. Acervo: Rio de Janeiro, 2011, p. 2.

22 ARTIGO 19. O direito do público a estar informado. Princípios sobre a legislação de liberdade de informação. Artigo 19: Londres, 1999. 0 Disponível em: <http://www.article19.org/data/files/pdfs/standards/public-right-to-know-portuguese.pdf>. Acesso em 09 nov. 2012.

23 INTERNACIONAL. Parceria para o Governo Aberto. Declaração de Governo Aberto. Disponível em: <http://www.opengovpartnership.org/sites/www.opengovpartnership.org/files/page_files/Declaracao_de Governo_Aberto.pdf>. Acesso em 08 nov. 2012.

${ }^{24}$ Ibidem.

REDESG / Revista Direitos Emergentes na Sociedade Global - www.ufsm.br/redesg v. 1, n. 2, jul.dez/2012 Revista do Programa de Pós-graduaÇÃo em DiReITo da Universidade Federal de SANTA MARIA - www.ufsm.br/ppgd
} 
facilitam a troca de informações, participação pública e colaboração"25. 0 reconhecimento da necessidade de adoção dessas práticas na desenvoltura do governo aberto e da cultura de acesso, por meio dessa parceria internacional, aliada à promulgação Lei de Acesso à Informação, demonstra a preocupação do Estado Brasileiro em implementar a transparência ativa.

Outrossim, convém destacar que desde 2004, o Governo Federal, por iniciativa da Controladoria-Geral da União (CGU), criou o Portal da Transparência ${ }^{26}$, o qual representou marco inicial quanto à efetivação do direito fundamental de acesso à informação, em que pese a inexistência de legislação específica na época. Segundo consta no site:

O Governo brasileiro acredita que a transparência é o melhor antídoto contra corrupção, dado que ela é mais um mecanismo indutor de que os gestores públicos ajam com responsabilidade e permite que a sociedade, com informações, colabore com o controle das ações de seus governantes, no intuito de checar se os recursos públicos estão sendo usados como deveriam.

Salienta-se, ademais, que, desde 16 de março de 2006, os órgãos e entidades da Administração Pública Federal devem criar páginas na Internet para a divulgação de dados e informações, conforme previsto na Portaria $n^{\circ} 140^{27}$. Disso se depreende que nesse contexto de evolução normativa regulamentar (por meio de atos administrativos) e implementação de mecanismos que visam à transparência no Poder Público, a Lei de Acesso à Informação merece preponderância, considerando, sobretudo, a sua abrangência. A referida Lei se aplica à União, Estados, Distrito Federal e Municípios, consoante prevê o artigo $1^{\circ}$. Também se subordinam ao regime da Lei: I) os órgãos públicos integrantes da administração direta dos Poderes Executivo, Legislativo, incluindo as Cortes de Contas, e Judiciário e do Ministério Público; II) as autarquias, as fundações públicas, as empresas públicas, as sociedades de economia mista e demais entidades controladas direta ou indiretamente pela União, Estados, Distrito Federal e Municípios.

\footnotetext{
${ }^{25}$ Ibidem.

26 BRASIL. Controladoria-Geral da União. Portal da Transparência. Disponível em: <http://www. portaldatransparencia.gov.br>. Acesso em 08 nov. 2012.

${ }^{27}$ Idem. Portaria Interministerial $n^{\circ} 140$, de 16 de março de 2006. Disciplina a divulgação de dados e informações pelos órgãos e entidades da Administração Pública Federal, por meio da rede mundial de computadores - internet, e dá outras providências. Disponível em: < http://www.cgu.gov.br/Legislacao/Arquivos/Portarias/Portaria_Interministerial.pdf>. Acesso em: 25 jul. 2012.

REDESG / Revista Direitos Emergentes na Sociedade Global - www.ufsm.br/redesg v. 1, n. 2, jul.dez/2012

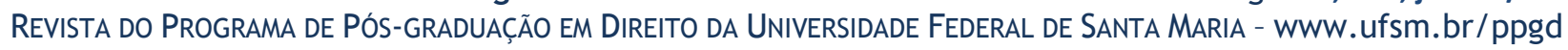


Esse dever de máxima divulgação por todos os entes acima descritos é previsto nos artigo $6^{\circ 28}$, I e $8^{\circ 29}$ da Lei $n^{\circ} 12.527$, sendo que a informação deve ser disponibilizada de forma transparente, clara e em linguagem de fácil compreensão $0^{30}$, com a vedação da exigência da motivação para a solicitação de interesse público ${ }^{31}$. A legislação elenca, ainda, no § 1ำ do artigo $8^{\circ 32}$ os seguintes requisitos mínimos para o exercício dessa divulgação de informações pelo Poder Público:
I - registro das competências e estrutura organizacional, endereços e telefones das respectivas unidades e horários de atendimento ao público;
II - registros de quaisquer repasses ou transferências de recursos financeiros;
III - registros das despesas;
IV - informações concernentes a procedimentos licitatórios, inclusive os respectivos editais e resultados, bem como a todos os contratos celebrados;
$\checkmark$ - dados gerais para o acompanhamento de programas, ações, projetos e obras de órgãos e entidades; e
$\mathrm{VI}$ - respostas a perguntas mais frequentes da sociedade.

Tais informações possuem fundamental importância no que tange ao exercício da transparência ativa, possibilitando o controle social e a participação popular. Diante da necessidade de que seja implementada a cultura do acesso e, consequentemente, efetivado o direito fundamental à informação, no próximo tópico, será verificado - por meio da análise dos

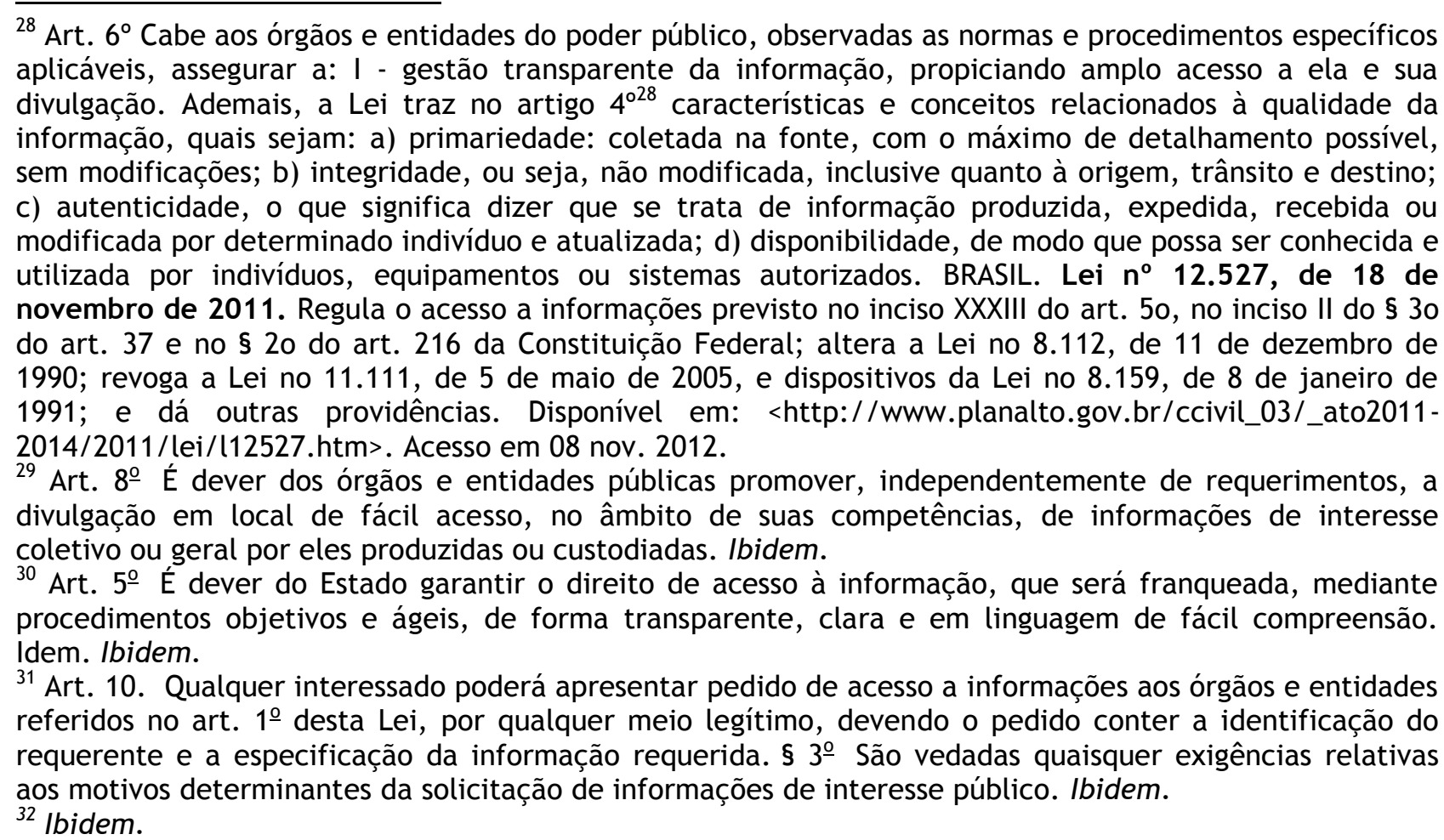

REDESG / Revista Direitos Emergentes na Sociedade Global - www.ufsm.br/redesg v. 1, n. 2, jul.dez/2012 ReVISTA do Programa de Pós-graduação em DiReito da Universidade Federal de SANTA MARIA - www.ufsm.br/ppgd 
respectivos sites e portais-, se na prática o Poder Judiciário, no âmbito dos Tribunais Regionais Federais, têm cumprido tais determinações mínimas, trazidas pela Lei 12.527/11.

Acompanhando a revolução tecnológica, a qual trouxe novas perspectivas para a organização do Poder Público, a terceira diretriz diz respeito à utilização de meios de comunicação viabilizados pela tecnologia da informação. Em face ao avanço da tecnologia "o passo mais notável da atividade da administração pública ocorreu com a utilização, de forma generalizada, da informatização"33. Porém, “a universalidade da Web só pode ser garantida e aprofundada com um modelo de governança democrático e pluralista que tenha foco no acesso por todos e na sua própria evolução tecnológica"34. A democracia também possui relação com a interface digital do Estado, pois a utilização da Internet, sobretudo, de sites e portais oficiais, representa hoje o principal canal de informação entre a esfera governamental e civil. Isso, pois, as ferramentas online são consideradas "instrumentos capazes de influir no aumento do engajamento político do cidadão; capazes de tornar o Estado mais transparente; de fortalecer processos de accountability e de criar uma ambiência própria para deliberação pública" ${ }^{35}$, dimensões estas necessárias para a consolidação da democracia.

Nesse ponto, merece destaque a importância das Tecnologias da Informação e da Comunicação (TIC'S), as quais, segundo Ricardo Sebastián Piana ${ }^{36}$, "son el conjunto de herramientas y de infraestructuras que se utilizan para recoger, almacenar, tratar, difundir o transmitir información". O Comitê Gestor da Internet no Brasil (CGI) ${ }^{37}$ salienta que as TIC's permitem a disponibilização de serviços, com destaque para a Internet - rápida, eficiente e customizada - e destaca o aumento da aproximação e da comunicação entre Estado e sociedade, além da qualificação do atendimento ao cidadão, da redução da complexidade de processos internos e dos custos para o governo.

33 FREITAS, Cinthia Obladen de Almendra (Org.). Direito e Questões Tecnológicas: aplicados no desenvolvimento social. Curitiba: Juruá, 2008, p. 74.

${ }^{34}$ BRASIL. Comitê Gestor da Internet no Brasil. Dimensões e características da Web brasileira: um estudo do .gov.br. 2010. Disponível em: <http://www.cgi.br/publicacoes/pesquisas/govbr/cgibr-nicbr-censowebgovbr-2010.pdf>. Acesso em 09 nov. 2012.

${ }^{35}$ FREITAS, Cinthia Obladen de Almendra (Org.). Direito e Questões Tecnológicas: aplicados no desenvolvimento social. Curitiba: Juruá, 2008, p. 23.

${ }^{36}$ PIANA, Ricardo Sebastián. Gobierno elecrónico: gobierno, tecnologias y reformas. $1^{\text {a }}$ ed. La Plata: Univ. Nacional de La Plata, 2007, p.65.

37 Brasil, op. cit. Neutralidade na Rede: Internet para todos. Revista .br, Ano 03, edição 04, 2011. Disponível em: <http://www.cgi.br/publicacoes/revista/edicao04/cgibr-revistabr-ed4.pdf>. Acesso em: 09 nov. 2012.

REDESG / Revista Direitos Emergentes na Sociedade Global - www.ufsm.br/redesg v. 1, n. 2, jul.dez/2012

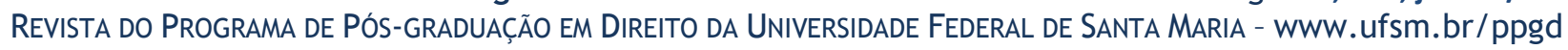


Assim, o avanço das TIC'S possui relação direta com o relacionamento da sociedade com a informação, visto que este "aumentou a capacidade de a população fiscalizar o poder público e participar dos processos de tomada de decisão. Com isso, a informação se tornou ainda mais importante para os cidadãos [...], pelo respeito do direito de acesso à informação"38. Com efeito, percebe-se que além de proporcionar a divulgação da informação em um curto espaço de tempo e com amplo alcance, a Internet se mostra um meio adequado e eficiente para a comunicação e interação entre o Poder Público e a sociedade, revelando seu potencial democrático ${ }^{39}$, na medida em que o "formato digital promove maior visibilidade, o que possibilita, indiretamente, maior transparência e controle da sociedade sobre aquilo que está sendo feito pelo ente público" ${ }^{40}$.

Conforme afirmado por Bruno Miragem ${ }^{41}$, o controle social abrange o acesso do cidadão a "informações sobre a ação dos órgãos e entes estatais de modo a permitir questionar, debater e impugnar decisões adotadas por agentes públicos”. Porém, ao entender que o controle social não depende somente do acesso à informação, o Autor enfatiza que a efetividade da publicidade e da transparência administrativa exige que o Estado assegure a possibilidade real de intervenção do cidadão.

Nesta senda, ao discorrer das possibilidades de acesso à informação pela Internet, Vanderlei Siraque ${ }^{42}$ enfatiza que a rede de computadores desempenha uma função importante no aspecto da participação popular e do controle social, e permite a prestação de contas; informações sobre os serviços públicos e o modo de acesso; agendas de interesse público; realização de debates e seminários e, sobretudo, o "acolhimento de sugestões, representações, reclamações, reivindicações, solicitação de informação e certidões".

Diante da modernização da Administração Pública no Brasil e, cônscio desse potencial que as TIC'S possuem para a promoção da transparência pública, o legislador estabeleceu no artigo $8^{\circ}$, § $2^{\circ}$, a obrigatoriedade do exercício da transparência ativa, pelos órgãos e entidades

\footnotetext{
${ }^{38}$ Acesso à informação e controle social das políticas públicas; coordenado por Guilherme Canela e Solano Nacimento. Brasília, DF: ANDI, ARTIGO 19, 2009, p.16.

${ }^{39}$ PINHO, José Antônio Gomes de. Investigando portais de governo eletrônico de estados no Brasil: muita tecnologia, pouca democracia. Rio de Janeiro: Revista de Administração Pública, v. 42, n. 3, maijun. 2008.

${ }_{40}$ PINHEIRO, Patrícia Peck. Direito Digital. 4 ed. rev., atual. e ampl. São Paulo: Saraiva, 2010, p. 277.

${ }^{41}$ MIRAGEM, Bruno. A Nova Administração Pública e o Direito Administrativo. São Paulo: Editora Revista dos Tribunais, 2011, p. 320.

42 SIRAQUE, Vanderlei. Controle social da função administrativa do Estado: possibilidades e limites da Constituição Federal de 1988. 2 ed. São Paulo: Saraiva, 2009, p. 135.

REDESG / Revista Direitos Emergentes na Sociedade Global - www.ufsm.br/redesg v. 1, n. 2, jul.dez/2012 ReVISTA do Programa de Pós-graduação em DiReito da Universidade Federal de SANTA MARIA - www.ufsm.br/ppgd
} 
DESAFIOS À CONCRETIZAÇÃO DA TRANSPARÊNCIA ATIVA NA INTERNET, À LUZ DA LEI DE ACESSO À INFORMAÇÃO PÚBLICA: análise dos portais dos Tribunais Regionais Federais

públicas, em sítios oficiais da rede mundial de computadores ${ }^{43}$. Tais sites, além de publicar as informações mínimas descritas no artigo $8^{\mathrm{a}}, \$ 1^{\circ}$, anteriormente abordadas, devem respeitar os requisitos constantes no $\S 3^{0^{44}}$ do mesmo artigo, dentre os quais se sobressai o efetivo acesso a uma informação objetiva, clara, transparente, compreensível, autêntica, íntegra e atualizada, bem como a necessidade de que os portais indiquem de que forma o cidadão pode se comunicar com o órgão público (instrumento de consolidação da transparência passiva ${ }^{45}$ ) e, por fim, a acessibilidade de conteúdo aos portadores de deficiência.

A partir dessas considerações, é possível constatar que a nova legislação consagra a necessidade de que seja implementada no Brasil uma cultura de acesso, com a finalidade de efetivar o direito à informação. Nesse aspecto, se destaca o dever de transparência ativa do Estado e a importância da utilização das Tecnologias da Informação e da Comunicação (TIC's) para a divulgação de informações e comunicação/interação entre governo e sociedade.

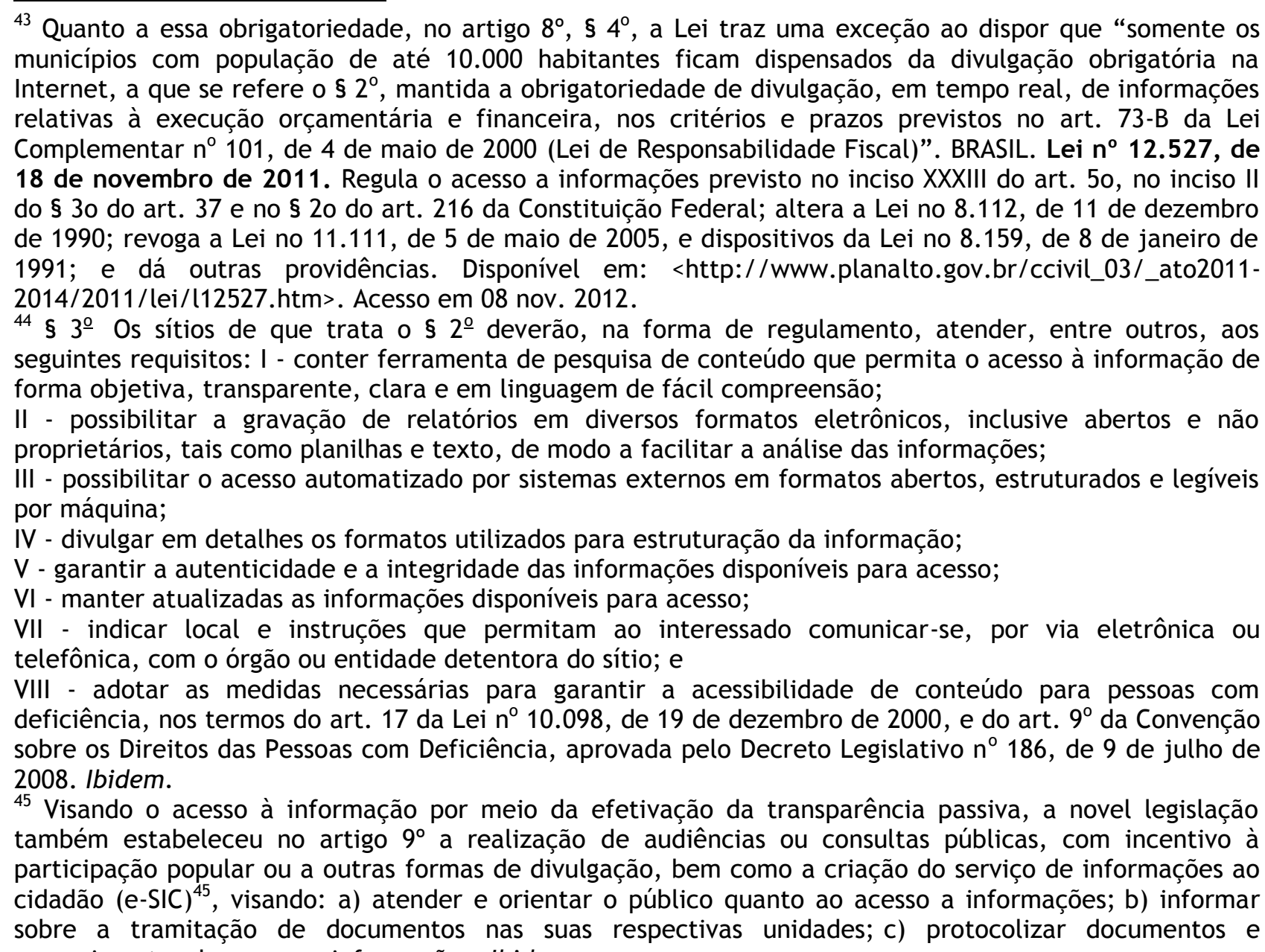
requerimentos de acesso a informações. Ibidem.

REDESG / Revista Direitos Emergentes na Sociedade Global - www.ufsm.br/redesg v. 1, n. 2, jul.dez/2012

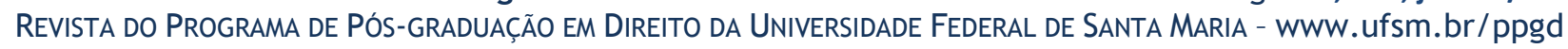


Superada a percepção teórica acerca da mudança de paradigma que estabelece a publicidade e a transparência como regra e o sigilo como exceção, é importante que se observe se e como o Poder Público vem cumprindo a Lei 12.527/11, porquando a mera previsão legal do dever estatal não assegura, por si, no plano concreto, a eficácia do direito fundamental ora abordado.

Contribuindo para esta imperiosa análise, o próximo tópico, por meio de um exame prático, restrito aos portais dos Tribunais Regionais Federais do Poder Judiciário, localizados na Internet, cotejando-se com as exigências legais que foram demonstradas neste tópico, objetiva verificar quais são os desafios à efetivação da transparência ativa nestes espaços de comunicação, destacando-se as fragilidades dos sites e novas perspectivas para o Estado Brasileiro no cumprimento da Lei de Acesso à Informação.

\section{DESAFIOS À EFETIVAÇÃO DA TRANSPARÊNCIA ATIVA NOS TERMOS DA}

\section{LEI No 12.527/11: uma análise dos portais dos Tribunais Regionais Federais}

A Lei $n^{\circ} 12.527 / 11$, através do seu art. $8^{\circ}, \$ 1^{\circ}$ - citado no tópico anterior - impôs o dever aos órgãos e entidades públicas de promoverem, a despeito de requerimento, a divulgação de informações de interesse coletivo ou geral por eles produzidas, devendo constar, no mínimo, aquelas relativas aos temas elencados nos respectivos incisos do dispositivo. Complementarmente, o $\$ 2^{\circ}$ do mesmo dispositivo legal obrigou que a divulgação destas informações também ocorra nos sítios oficiais da rede mundial de computadores.

Afinal, o exercício do dever de transparência ativa deve estar em consonância com a evolução das Tecnologias de Informação e Comunicação (TIC's), não bastando que as informações de interesse coletivo sejam publicadas apenas nos ambientes físicos em que desempenhadas concretamente as atividades administrativas. Contudo, não se pode olvidar que a mudança paradigmática abordada no item anterior, no que tange à transparência ativa, conduz os órgãos e entidades públicas a cenário desafiador, exigindo-lhes novas competências técnicas, organizacionais e estruturais, sem os quais a eficácia normativa restará abalada negativamente.

Objetivando identificar alguns dos elementos deste grande desafio, foi realizada observação direta, sistemática e não participativa em sites e portais dos cinco Tribunais REDESG / Revista Direitos Emergentes na Sociedade Global - www.ufsm.br/redesg v. 1, n. 2, jul.dez/2012 Revista do Programa de Pós-graduaÇão em Direito da Universidade Federal de Santa MaRia - www.ufsm.br/ppgd 
Regionais Federais do Poder Judiciário ${ }^{46}$ (doravante referidos como TRF1, TRF2, TRF3, TRF4 e TRF5), especificamente em relação: a)ao cumprimento da totalidade dos deveres mínimos de transparência ativa, abordados pelo art. $8^{\circ}, \$ 1^{\circ}$, I, II, III, IV,V e VI, da Lei $n^{\circ} 12.527 / 11^{47}$; e b) à atenção aos requisitos previstos no $\operatorname{art.} 8^{\circ}, \S 3^{\circ}, \mathrm{I}$, VI e VII, da Lei $n^{\circ} 12.527 / 11^{48}$.

A observação transcorreu-se no mês de novembro de 2012, almejando identificar, num primeiro momento, se as informações e possibilidades/ferramentas de acesso foram encontradas nos sites e portais e como tal efetivação ocorre. Para melhor compreensão das conclusões, a análise foi resumida em itens apartados (itens de “a” a “h”), de acordo com o conteúdo dos incisos dos dispositivos legais norteadores - metodologia esta que igualmente conduzirá a exposição dos resultados, a partir do parágrafo seguinte. Após explicitar as constatações da observação dos portais, serão abordadas as conclusões e desafios percebidos à concretização da transparência ativa na internet (item “i”), de acordo com a finalidade, diretrizes e princípios da Lei $\mathrm{n}^{\circ} 12.527 / 11$, dissertados na primeira parte do presente estudo. Prossegue-se, portanto, com a apresentação dos resultados:

a) registro das competências e estrutura organizacional, endereços e telefones das respectivas unidades e horários de atendimento ao público (art. $8^{\circ}, \S 1^{\circ}$, I, Lei $\mathrm{n}^{\circ} 12.527 / 11$ ):

Todos os portais analisados divulgam informações sobre sua competência e composição, divergindo apenas na forma de disposição das mesmas. Nos portais do TRF2 e TRF3, tais informações estão dispostas em página que abre ao clicar nos itens "Acesso à informação institucional" e "transparência pública", respectivamente, constantes da página inicial. Nos sites dos demais Tribunais, estas informações estão preconizadas no item "institucional”, localizado no menu das páginas iniciais.

Igual resultado não foi apurado em relação aos horários de atendimento do público, na medida em que tal informação foi encontrada apenas nos portais dos TRFs 2 e 3 (este último apenas em relação ao funcionamento do setor de ouvidoria), tendo sido constatado que os

\footnotetext{
${ }^{46}$ BRASIL. Tribunal Regional Federal da $1^{\text {a }}$ Região. Página inicial. Disponível em: <www.trf1.jus.br>. Acesso em 07 nov. 2012; Idem, Tribunal Regional Federal da $2^{\mathrm{a}}$ Região. Página inicial. Disponível em: <www.trf2.jus.br>. Acesso em 07 nov. 2012; Idem, Tribunal Regional Federal da $3^{a}$ Região. Página inicial. Disponível em: <www.trf3.jus.br>. Acesso em 07 nov. 2012; Idem, Tribunal Regional Federal da $4^{a}$ Região. Página inicial. Disponível em: <www.trf4.jus.br>. Acesso em 07 nov.2012; e Idem. Tribunal Regional Federal da 5a Região. Página inicial. Disponível em: <www.trf5.jus.br>. Acesso em 07 nov. 2012.

${ }^{47}$ Devidamente citados na página 10 do presente artigo.

${ }^{48}$ Em sua integralidade ditado na nota de rodapé $n^{\circ} 45$.

REDESG / Revista Direitos Emergentes na Sociedade Global - www.ufsm.br/redesg v. 1, n. 2, jul.dez/2012 Revista do Programa de Pós-graduaçÃo em DiREITO dA Universidade FEderal de SANTA MARIA - www.ufsm.br/ppgd
} 
DESAFIOS À CONCRETIZAÇÃO DA TRANSPARÊNCIA ATIVA NA INTERNET, À LUZ DA LEI DE ACESSO À INFORMAÇÃO PÚBLICA: análise dos portais dos Tribunais Regionais Federais

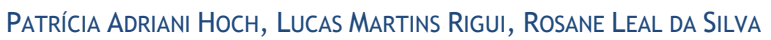

demais restringem-se a informar ao cidadão a possibilidade de estabelecimento de comunicação através de ouvidoria on-line.

Destaca-se de forma positiva a preocupação do portal do TRF2 com mencionada informação, existindo uma página específica sobre atendimento ao cidadão, no menu "acesso à informação", caracterizada pela clareza e acessibilidade, ao dispor de todas as formas de contato possíveis, inclusive de atendimento pessoal, conseguintes horários e órgãos ${ }^{49}$.

b) registros de despesas e quaisquer repasses ou transferências de recursos financeiros (art. $8^{\circ}, \S 1^{\circ}$, II e III, Lei $\left.\mathrm{n}^{\circ} 12.527 / 11\right)$ :

Relativamente às informações financeiras, o resultado da observação dos portais foi, de modo geral, extremamente positivo, principalmente porque sua divulgação ativa já havia sido regulamentada anteriormente à vigência da Lei $n^{\circ} 12.527 / 11$. Seguindo a tradição do Poder Executivo Federal $^{50}$ e impulsionado pela crescente luta pela moralidade administrativa, 0 Conselho Nacional de Justiça (CNJ) publicou, em 2009, as Resoluções $n^{\circ} 79^{51}$ e $102^{52}$, as quais

\footnotetext{
${ }^{49}$ Nesta mesma página, o TRF da $2^{\text {a }}$ Região informa que dispõe de serviço de informação aos interessados no balcão da Seção de Atendimento ao Cidadão, que também pode ser contatado por telefone ou e-mail. BRASIL. Tribunal Regional Federal da $2^{\text {a }}$ Região. Atendimento ao cidadão. Disponível em: < http://www.trf2.jus.br/atendimento/atendimento/atendimento2.aspx?menu=Acesso\%20\%C3\%A0\%20Infor ma\%C3\%A7\%C3\%A3o>. Acesso em 07 nov.2012.

${ }^{50} \mathrm{Em} 16$ de março de 2006 foi publicada a Portaria Interministerial $n^{\circ}$ 140, que disciplinou a divulgação de dados e informações pelos órgãos e entidades da Administração Pública Federal, por meio da rede mundial de computadores - internet. Com efeito, tal portaria estabeleceu as regras de divulgação de informações relativas à execução orçamentária e financeira dos órgãos e entidades da Administração Pública Federal direta e indireta, exclusivamente para fins de controle social. BRASIL. Portaria Interministerial $n^{\circ} 140$, de 16 de março de 2006. Disciplina a divulgação de dados e informações pelos órgãos e entidades da Administração Pública Federal, por meio da rede mundial de computadores - internet, e dá outras providências. Disponível em:

http://www.cgu.gov.br/Legislacao/Arquivos/Portarias/Portaria_Interministerial.pdf>. Acesso em: 25 jul. 2012.

${ }^{51}$ A Resolução $n^{\circ} 79$ do CNJ dispõe sobre a transparência na divulgação das atividades dos órgãos do Poder Judiciário e estabelece, como princípio da divulgação das atividades dos órgãos, a preferência pela utilização de meios eletrônicos em detrimento dos impressos. BRASIL. Conselho Nacional de Justiça. Resolução $n^{\circ} 79$. Dispõe sobre a transparência na divulgação das atividades do Poder Judiciário brasileiro e dá outras providências. Disponível em: < http://www.cnj.jus.br/atos-administrativos/atos-dapresidencia/323-resolucoes/12197-resolucao-no-79-de-9-de-junho-de-2009 >. Acesso em 08 nov. 2012.

52 Segundo o art. $1^{\circ}$ da Resolução $n^{\circ} 102$ do CNJ: "Os tribunais indicados nos incisos II a VII do Art. 92 da Constituição Federal, o Conselho Nacional de Justiça e o Conselho da Justiça Federal publicarão, em seus sítios na rede mundial de computadores e encaminharão ao Conselho Nacional de Justiça, observados as definições e prazos constantes desta Resolução: I - os dados de sua gestão orçamentária e financeira, na forma dos Anexos I e II desta Resolução; II - as informações sobre as respectivas estruturas remuneratórias, quantitativos de pessoal efetivo e comissionado, e origem funcional dos ocupantes dos cargos em comissão; III - a relação de membros da magistratura e demais agentes públicos; IV - a relação dos empregados de empresas contratadas em exercício nos órgãos; e V - a relação dos servidores e/ou empregados não integrantes do quadro próprio em exercício no órgão, excluídos os REDESG / Revista Direitos Emergentes na Sociedade Global - www.ufsm.br/redesg v. 1, n. 2, jul.dez/2012 Revista do Programa de Pós-graduaÇão em Direito da Universidade Federal de Santa Maria - www.ufsm.br/ppgd
} 
dispõem sobre a regulamentação da publicação de informações alusivas à gestão orçamentária e financeira, aos quadros de pessoal e respectivas estruturas remuneratórias dos tribunais e conselhos.

Tais Resoluções obrigaram os gestores dos órgãos integrantes do Poder Judiciário a divulgarem as mesmas informações cuja publicação a Lei 12.527/11 atualmente torna cogente, de modo que todos os portais analisados possuem informações globais e consolidadas de suas despesas mensais e repasses, classificadas e definidas na forma do art $2^{\circ}$ da Resolução $n^{\circ} 102$ do $\mathrm{CNJ}^{53}$.

Outrossim, à exceção dos sites do TRF5 e TRF4 - que direcionam o usuário para o Portal da Transparência do Poder Judiciário ${ }^{54}$ - os demais portais publicam em sistema próprio (diversos entre si) informações sobre todas as compras realizadas pelo órgão, em determinado período a ser pesquisado, com detalhamento do objeto contratual e particular envolvido.

c) informações concernentes a procedimentos licitatórios, inclusive os respectivos editais e resultados, bem como a todos os contratos celebrados (art. $8^{\circ}, \$ 1^{\circ}$, IV, Lei $n^{\circ}$ 12.527/11):

A unanimidade foram encontradas informações sobre os procedimentos licitatórios do órgão (em andamento e recentemente encerrados), com editais disponíveis. 0 interior teor dos contratos celebrados não se encontram disponíveis nos sites. Porém, à exceção do portal do TRF5, foram facilmente encontrados dados das contratações realizadas (empresa contratada, número do processo, data da celebração, objeto e valor), com sistemas de busca variados, mas sempre classificados pelo período temporal desejado, o que permite um pedido de informações

ocupantes de cargo em comissão ou função de confiança. BRASIL. Conselho Nacional de Justiça. Resolução $n^{\circ}$ 102. Dispõe sobre a regulamentação da publicação de informações alusivas à gestão orçamentária e financeira, aos quadros de pessoal e respectivas estruturas remuneratórias dos tribunais e conselhos. Disponível em: < http://www.cnj.jus.br/atos-administrativos/atos-dapresidencia/resolucoespresidencia/12218-resolucao-no-102-de-15-de-dezembro-de-2009 >. Acesso em 08 nov. 2012.

${ }^{53}$ A citação do dispositivo foi dispensada em razão de sua extensão e da limitação de páginas do presente artigo, podendo o mesmo ser acessado através do link <http://www.jf.jus.br/cjf/cjf/transparenciapublica/transperencia-no-cjf/uniformizacao-normativa/leis-e-normas-aplicaveis/resolucao-cnj-102-09>.

54 Segundo informações contidas no site do Portal, o mesmo é gerido pelo Conselho Nacional de Justiça e que visa disponibilizar ao pleno conhecimento e acompanhamento da sociedade informações atinentes à execução orçamentária e financeira do Poder Judiciário, sendo alimentado, diariamente, com os documentos de execução orçamentária e financeira emitidos no Sistema Integrado de Administração Financeira do Governo Federal - SIAFI. BRASIL. Conselho Nacional de Justiça. Portal da Transparência. Disponível em: < http://www.portaltransparencia.jus.br/despesas/>. Acesso em 13 nov. 2012.

REDESG / Revista Direitos Emergentes na Sociedade Global - www.ufsm.br/redesg v. 1, n. 2, jul.dez/2012 Revista do Programa de Pós-gRaduaÇão EM DIREITO da UnIVERSIDAde Federal de SANTA MARIA - www.ufsm.br/ppgd 
ulterior pelo cidadão, solicitando cópia do documento, em caso de interesse, em virtude da transparência passiva.

No caso do TRF5, a pesquisa dos contratos realizados aparenta exigir os dados do instrumento desejado, diversamente das pesquisas em outros portais, em que é possível consultar de modo genérico por período temporal. Utiliza-se o verbo "aparentar" na medida em que na execução da análise a ausência do preenchimento destes dados resultou em uma página com erro; porém, não se pode deixar de considerar a possibilidade de ser apenas um problema técnico temporário, manifestado no período de observação.

d) dados gerais para o acompanhamento de programas, ações, projetos e obras de órgãos e entidades ( $\operatorname{art.} 8^{\circ}, \S 1^{\circ}, \mathrm{V}$, Lei $\left.\mathrm{n}^{\circ} 12.527 / 11\right)$ :

A observação demonstrou que todos os portais publicam informações sobre as metas e objetivos do respectivo planejamento estratégico - bem como da Justiça Federal - objetivando demonstrar à sociedade os programas, ações e projetos pautados e em execução para aprimorar a qualidade do serviço público prestado ${ }^{55}$.

Porém, tal qual nos demais objetos de pesquisa, não há uma uniformidade em relação à localização das informações nos sites. No portal do TRF2, há um item denominado "gestão e planejamento", localizado dentro da página sobre transparência pública, que é acessada a partir do menu “Acesso à informação", contido na página inicial. Diversamente, nos portais dos TRFs 1 , 4 e 5, tais informações encontram-se inseridas dentro das páginas "gestão estratégica" e "planejamento", que podem ser acessadas a partir do menu "institucional", descrito na home page. Por fim, encontrar tais informações no site do TRF3 somente foi possível a partir do sistema de busca de conteúdo, porquanto não há referências a planejamento ou gestão estratégica na página inicial.

Dentre todos, o portal do TRF5 merece destaque, haja vista disponibilizar um vasto portal de planejamento estratégico, dispondo de arquivos para download, regras sobre projetos do órgão, regulamentos, notícias relacionadas à gestão e artigos, contribuindo positivamente para o acesso à informação. Ademais, todos os portais apresentam notícias relacionadas ao

\footnotetext{
${ }^{55} \mathrm{O}$ planejamento estratégico dos Tribunais Regionais Federais é realizado com fulcro na Resolução $\mathrm{n}^{\circ} 70$ do Conselho Nacional de Justiça. BRASIL. Conselho Nacional de Justiça. Resolução $n^{\circ} 70$. Dispõe sobre o Planejamento e a Gestão Estratégica no âmbito do Poder Judiciário e dá outras providências. Disponível em < http://www.cnj.jus.br/gestao-e-planejamento/gestao-e-planejamento-do-judiciario/resolucao-n-70 $>$. Acesso em 08 nov. 2012.

REDESG / Revista Direitos Emergentes na Sociedade Global - www.ufsm.br/redesg v. 1, n. 2, jul.dez/2012

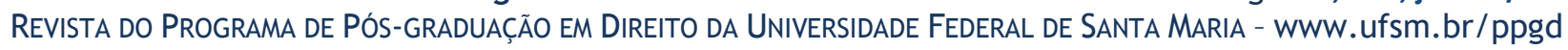


órgão, suas decisões, programas e projetos ${ }^{56}$. Neste item, revelaram-se positivos os portais dos TRFs 4 e 5, por possuirem, em sua página, vários instrumentos de comunicação, através do facebook, twitter e RSS.

e) respostas a perguntas mais frequentes da sociedade (art. $8^{\circ}, \$ 1^{\circ}, \mathrm{VI}$, Lei $\mathrm{n}^{\circ}$ 12.527/11):

Neste item residiram as maiores diferenças entre os portais, constatando-se que cada qual enfrenta a questão de um modo particular. No portal do TRF1, no item atinente à ouvidoria, existe uma página sobre perguntas frequentes, com 11 (onze) questionamentos, cujos objetos variam entre dificuldades operacionais jurídicas e relacionadas aos interesses de cidadãos não operadores do direito (tais como forma de obter certidões, interior teor de acórdãos e acompanhar manifestações realizadas perante ouvidoria).

$\mathrm{Na}$ página inicial do TRF2, há uma página de perguntas frequentes, com questões básicas sobre o direito à informação (iniciativa ímpar e louvável) e específicas, com 36 (trinta e seis) possibilidades, em sua maioria de interesse da sociedade. Porém, as respostas a estas perguntas ligadas à atividade do órgão são curtas e muito objetivas, exigindo conhecimento prévio da estrutura administrativa deste para sua compreensão.

Os melhores resultados foram percebidos na observação do site do TRF4, o qual dispõe de uma página de perguntas frequentes com 14 (quatorze) questões, em sua maioria ligadas às dúvidas que a sociedade pode ter em relação à atividade jurisdicional (como explicações sobre expedição de Requisições de Pequeno Valor, precatórios, procedimento de pagamento de custas e formas para obter cópias). Ademais, as perguntas foram respondidas de forma satisfatória, apresentando conhecimento e informações ao interessado.

Na parte inferior da home page do TRF5, foi encontrada uma página de orientações (não de perguntas frequentes). Porém, constatou-se que as mesmas são técnicas e em sua grande maioria dirigidas aos operadores jurídicos, ao abordarem: tabelas de correção monetárias; manual de orientação para cálculos; orientações para cadastramento de fornecedores; orientação quanto aos procedimentos relacionados a Precatórios e RPV; relação dos Repositórios

56 O CNJ, através da Resolução $n^{\circ} 85$, que dispõe sobre a comunicação social no âmbito do Poder Judiciário, determinou, através do seu art. $3^{\circ}$, III, que as ações de comunicação social do Poder Judiciário compreenderiam a área da comunicação digital. BRASIL. Conselho Nacional de Justiça. Resolução $\mathbf{n}^{\circ} \mathbf{8 5}$. Dispõe sobre a Comunicação Social no âmbito do Poder Judiciário. Disponível em: < http://www.cnj.jus.br/atos-administrativos/atos-da-presidencia/323-resolucoes/12200-resolucao-no-85de-08-de-setembro-de-2009>. Acesso em 12 nov. 2012.

REDESG / Revista Direitos Emergentes na Sociedade Global - www.ufsm.br/redesg v. 1, n. 2, jul.dez/2012 Revista do Programa de Pós-graduaçÃo em DiREITO dA Universidade FEderal de SANTA MARIA - www.ufsm.br/ppgd 
Oficiais de Jurisprudência do TRF $5^{a}$ Região; Ato $\mathrm{n}^{\circ}$ 642: tabela única de custas da Justiça Federal da $5^{\text {a }}$ Região; e tabelas de deflação.

Situação oposta foi verificada junto ao portal do TRF3, porquanto um item sobre perguntas frequentes foi encontrado apenas pelo sistema de busca de conteúdo (novamente, a exemplo do que ocorreu acerca do Planejamento Estratégico), sendo que as perguntas diziam respeito tão somente ao processo eletrônico e seu manuseio.

f) ferramenta de pesquisa de conteúdo que permita o acesso à informação de forma objetiva, transparente, clara e em linguagem de fácil compreensão; $\left(\operatorname{art.~} 8^{\circ}, \S 3^{\circ}\right.$, I, Lei $n^{\circ}$ 12.527/11):

Esta importantíssima ferramenta, que auxilia o usuário a rapidamente encontrar o conteúdo desejado no portal acessado, não foi encontrada em todos os sites observados. Com efeito, a pesquisa de conteúdo foi constatada apenas nas páginas iniciais dos TRFs $1,3^{57}$ e 5 , reservando-se os demais a disponibilizar um item de consulta de processos e jurisprudências. Ademais, entre os portais que apresentam a ferramenta, apenas no caso do TRF1 a pesquisa realizada não apresenta resultados com detalhes (como categoria e caminho), forçando o usuário a clicar nos mesmos para testar se dizem respeito a sua pretensão.

g) atualização das informações disponíveis para acesso $\left(\operatorname{art.} 8^{\circ}, \S 3^{\circ}, \mathrm{VI}\right.$, Lei $\mathrm{n}^{\circ}$ 12.527/11):

Tão importante quanto disponibilizar informações ao acesso público, está o dever de mantê-las atualizadas, afinal, sem tal providência o controle social e a concretização da cultura de acesso pela sociedade restam inviabilizados. A imperiosa observação a respeito deste item levou em consideração a atualização das informações relativas a três quesitos: 1) licitações e contratos; 2) notícias e comunicação social; e 3) projetos e ações.

A respeito dos dois quesitos iniciais, constatou-se um comportamento ativo de todos os portais. As notícias estavam atualizadas e recebiam renovações diárias. Os procedimentos licitatórios em andamento estavam todos disponíveis e recebiam atualização de acordo com o avanço de suas fases.

\footnotetext{
${ }^{57}$ No caso do portal do TRF3, a ferramente encontra-se disposta em um pequeno ícone situado na margem superior da página inicial, em formato de lupa, que necessita ser clicado para abrir uma nova página de pesquisa de conteúdo. Indubitavelmente, esta forma utilizada pode inviabilizar sua constatação a determinados usuários. BRASIL.Tribunal Regional Federal da $3^{a}$ Região. Página inicial. Disponível em: $<$ www.trf3.jus.br>. Acesso em 07 nov. 2012

REDESG / Revista Direitos Emergentes na Sociedade Global - www.ufsm.br/redesg v. 1, n. 2, jul.dez/2012 Revista do Programa de Pós-graduação em DiReITO da Universidade Federal de SANTA MARIA - www.ufsm.br/ppgd
} 
A despeito destes resultados positivos, não foram encontrados dados consolidados e atualizados sobre a evolução do planejamento estratégico dos órgãos, com resultados da avaliação do cumprimento das metas e desenvolvimento de projetos ${ }^{58}$. Conforme destacado no item "d" , todos os portais publicam informações sobre as metas e objetivos do respectivo planejamento estratégico, bem como da Justiça Federal, objetivando demonstrar à sociedade os programas, ações e projetos que foram pautados e estão em execução para aprimorar a qualidade do serviço público prestado.

Contudo, informações atualizadas sobre o estado de execução dos projetos e ações não são obtidas. Enquanto no Portal do TRF1 foram visualizadas apenas notícias do planejamento publicadas até o ano de 2010 e na página do TRF2 apenas o plano do quinquênio 2010-2014 foi disponibilizado, os portais dos TRFs 3,4 e 5 apresentam painéis de acompanhamento das metas, porém em alguns não há certeza sobre a última atualização (TRF3 e TRF4), e em outro as informações se mantém inalteradas desde dezembro de 2011 (TRF5). Este quadro negativo inviabiliza um acompanhamento mais efetivo por parte da sociedade sobre o desenvolvimento da gestão dos órgãos analisados e foi um dos pontos críticos da análise (ao lado do item "perguntas frequentes") que revelaram que a transparência ativa está longe de ser plenamente concretizada.

h) local e instruções que permitam ao interessado comunicar-se, por via eletrônica ou telefônica, com o órgão ou entidade detentora do sítio $\left(\operatorname{art.} 8^{\circ}, \S 3^{\circ}\right.$, VII, Lei $\left.n^{\circ} 12.527 / 11\right)$;

Resumidamente, todos os portais observados dispunham de sistema de ouvidoria online, permitindo a remessa de solicitações por via eletrônica. Ademais, igual resultado foi obtido em relação à disponibilização dos telefones para contato. Porém, o portal do TRF5, diversamente dos demais ${ }^{59}$, não apresentava instruções ao usuário do respectivo canal de comunicação, o que denota a ausência de preocupação da home page para a qualidade de acesso dos seus usuários.

\footnotetext{
${ }^{58}$ Avaliações estas que ocorrem nos termos do art. $5^{\circ}$ da Resolução $n^{\circ} 70$ do CNJ: "Art. $5^{\circ}$ Os tribunais promoverão Reuniões de Análise da Estratégia - RAE trimestrais para acompanhamento dos resultados das metas fixadas, oportunidade em que poderão promover ajustes e outras medidas necessárias à melhoria do desempenho." . BRASIL. Conselho Nacional de Justiça. Resolução $n^{\circ} 70$. Dispõe sobre o Planejamento e a Gestão Estratégica no âmbito do Poder Judiciário e dá outras providências. Disponível em: <http://www.cnj.jus.br/gestao-e-planejamento/gestao-e-planejamento-do-judiciario/resolucao-n-70>. Acesso em 13 nov.2012

${ }^{59}$ No site do TRF2, por exemplo, foram encontradas instruções sobre formas de comunicação, histórico e competência da ouvidoria. BRASIL. Tribunal Regional Federal da $2^{a}$ Região. Ouvidoria Geral da Justiça Federal da $2^{\text {a }}$ Região. Disponível em: < http://www.trf2.jus.br/ouvidoria/default.aspx >. Acesso em 08 nov. 2012.
}

REDESG / Revista Direitos Emergentes na Sociedade Global - www.ufsm.br/redesg v. 1, n. 2, jul.dez/2012 Revista do Programa de Pós-gRaduaÇão EM DIREITO da UnIVERSIDAde FEderal de SANTA MARIA - www.ufsm.br/ppgd 
A observação realizada, apesar de não ser exaustiva, possibilitou apresentar um panorama geral acerca do cumprimento da Lei $n^{\circ}$ 12.527/11 pelos Tribunais Regionais Federais, destacando-se as deficiências estruturais e estratégicas dos sites e portais, bem como as providências que podem ser adotadas, no sentido da efetivação do dever de transparência ativa no Brasil.

\section{CONCLUSÃO}

O reconhecimento do direito à informação, no Brasil, passou por um processo lento e gradativo de evolução. Apesar de ter sido elencado como fundamental no artigo no artigo $5^{\circ}$, XXXIII da Constituição Federal de 1988, somente foi regulamentado pela Lei 12.527, promulgada em 18 de novembro de 2011. Ao revés, a utilização das Tecnologias da Informação e da Comunicação (TIC's) aumenta de forma rápida e significativa.

Tais avanços tecnológicos, aliados à necessidade de implementação da cultura de acesso prevista na nova legislação, baseada na publicidade e na transparência como regra - em detrimento do sigilo -, fazem com que o Poder Público se aproprie e adote ferramentas e procedimentos para a efetivação do acesso à informação na Internet, além das mídias tradicionais.

Consoante destacado no presente trabalho, o formato digital traz inúmeras vantagens, no que tange à concretização do dever de transparência - principalmente ativa do Estado (independente de solicitação), tais como: a aproximação e a comunicação entre Estado e sociedade; aumento do desempenho e da eficiência da Administração Pública, aliado à qualificação do atendimento ao cidadão; da redução da complexidade de processos internos e dos custos para o governo. Além disso, merece destaque a contribuição do acesso à informação pública para o controle social e para a participação popular no Estado Democrático de Direito.

Diante do dever norteador de transparência pública e da importância do uso das TIC's para sua concretização, a Lei de Acesso à Informação, no artigo $8^{\circ}$, traz inúmeras disposições que obrigam a publicização de dados - sejam documentos, arquivos e estatísticas - de interesse geral ou coletivo, independentemente de requerimentos do cidadão, estabelecendo, inclusive, no $\S 1^{\circ}$ os requisitos mínimos para a realização dessa divulgação. 
A observação realizada nos portais dos Tribunais Regionais Federais permitiu constatar que no período investigado nenhum dos portais cumpria a integralidade dos deveres informacionais mínimos insculpidos no art. $8^{\circ}, \$ 1^{\circ}$ da Lei $n^{\circ} 12.527 / 11$ e os requisitos de publicação previstos nos incisos I, VI e VII, do $\$ 3^{\circ}$ do mesmo dispositivo legal.

Os sites descumpriam da seguinte forma os dispositivos legais supramencionados: a) o TRF1 não publicou os horários de atendimento ao público, bem como não disponibilizou ferramenta de pesquisa de conteúdo e não manteve de forma atualizada as informações sobre projetos, ações e planejamento estratégico; b) o portal do TRF2 também não continha a ferramenta de pesquisa de conteúdo e não apresentava informações complementares sobre seus projetos, programas e ações; c) o TRF3 não apresentou um rol de perguntas frequentes da sociedade, além de não ter atualizado o painel de execução do seu mapa estratégico de projetos e ações; d) o TRF4 disponibiliza ouvidoria on-line, mas não informa os horários de atendimento à coletividade em seus órgãos, tampouco disponibiliza ferramenta de busca de conteúdo aos usuários e data das últimas atualizações do painel de execução estratégica; e) o TRF5, por sua vez, também não disponibiliza a informação sobre os horários, não aborda as questões frequentes da sociedade (limitando-se a exarar orientações técnicas ligadas ao exercício da prática jurídica), além de não expor instruções para a utilização do setor de ouvidoria e ter atualizado seu painel de programas e projetos de gestão, pela última vez, em dezembro de 2011.

Porém, em alguns casos, ainda que presente a informação pesquisada (considerando-se cumprido o dever legal), alguns pontos negativos foram observados. No que tange à publicação dos contratos celebrados, o portal do TRF5 disponibiliza ferramenta de pesquisa que exige os dados do instrumento desejado, diversamente das pesquisas em outros portais, em que é possível consultar de modo genérico por período temporal. Tal exigência dificulta ou até mesmo inviabiliza o acesso à informação, bem como o exercício do controle social.

Além disso, apesar de todos os portais informarem acerca do mapa estratégico institucional, revelando metas, indicadores e projetos, não foram encontrados dados consolidados atualizados sobre a evolução dos respectivos planejamentos estratégicos, o que obriga o interessado a efetivar um requerimento de acesso a estas informações. Nesse ponto, há uma deficiência na transparência ativa, tendo em vista que a informação de caráter geral ou coletivo deve ser disponibilizada de forma espontânea pela Administração, conforme exposto no tópico anterior. Em decorrência, disso, o cidadão deverá buscar a informação, por meio de 
requerimento, consubstanciando na transparência meramente passiva, ao contrário do que prevê como regra a Lei $n^{\circ} 12.527 / 11$.

No portal do TRF2, apesar de estar elencada uma variedade significativa de perguntas específicas e frequentes da sociedade, com 36 (trinta e seis) possibilidades, as respostas a estas questões são curtas e muito objetivas, praticamente perpetuando a dúvida e obrigando contato direto com outros órgãos da estrutura administrativa. Essa postura novamente demostra o cumprimento deficitário do dever de transparência ativa.

Indubitavelmente, as Resoluções do $\mathrm{CNJ}$ de $\mathrm{n}^{\circ} 70,79,85$ e 102 (notas de rodapé $\mathrm{n}^{\circ} 51$, 52, 55 e 56), relativas ao exercício da transparência pública nos sites e portais dos tribunais do Poder Judiciário, ainda anteriores à publicação da Lei $\mathrm{n}^{\circ} 12.527 / 11$, influenciaram positivamente os resultados da observação, notadamente no que atine à publicação do planejamento estratégico (mapeamento, indicadores, metas e planos de ação), das despesas efetuadas com compras e contratos, dos relatórios de gestão fiscal, financeira e orçamentária e dos procedimentos licitatórios e seus resultados. Tal influência é tamanha que as principais deficiências encontradas - horários de atendimento ao público e perguntas frequentes da sociedade - são todas relacionadas a exigências realizadas pela Lei $n^{\circ}$ 12.527/11 que não haviam sido anteriormente regulamentadas pelo $\mathrm{CNJ}$.

Logo, é possível concluir que os portais consultados dedicaram-se, ainda anteriormente a novel legislação, ao cumprimento das exigências dispostas nos regulamentos administrativos do CNJ, não dispensando, até o presente momento, a mesma atenção em relação às obrigações legais do art. $8^{\circ}, \S 1^{\circ}$ e $3^{\circ}$ da Lei $n^{\circ} 12.527 / 11$ - elementos e requisitos mínimos de transparência ativa. Disso é possível depreender que aquelas exigências que são abarcadas tanto pela Lei de Acesso à Informação, como aquelas regulamentadas pelo CNJ, têm sido cumpridas. Por outro lado, as disposições que não foram disciplinadas pelo referido Conselho ainda não foram plenamente cumpridas, ainda que sejam deveres simples, como a publicação dos horários de atendimento ao público.

Revela-se, neste diapasão, o primeiro desafio à concretização plena da transparência ativa, a luz da Lei de Acesso à Informação Pública, na Internet, pelos Tribunais Regionais Federais: ultrapassar a cultura de cumprimento estrito das Resoluções do Conselho Nacional de Justiça e agir ativamente e com antecedência em relação a todos os deveres mínimos (elencados no presente artigo), ainda que não regulamentados pelo órgão citado. 
Outro desafio exposto durante a observação dos portais, que afeta direta e qualitativamente o desenvolvimento do controle social da administração (diretriz da Lei $\mathrm{n}^{\circ}$ 12.527/11 - art. $3^{\circ}$, “V”), é superar a problemática da variedade das formas de publicação das informações de interesse coletivo ora analisadas, que dificulta o efetivo acesso à informação. Todos os sites possuem uma metodologia de publicação própria, na medida em que não existe, no âmbito do Poder Judiciário, uma norma regulamentar (ou política) de padronização mínima sobre a forma de comunicação. Este contexto pulveriza e prejudica a informação, representando um obstáculo à realização do controle social, na medida em dificulta a intelegibilidade e a comparabilidade das mesmas entre os órgãos do Poder Judiciário.

Cabe salientar, ainda, que a ausência de uniformização e de interoperabilidade entre os órgãos, dentro, inclusive, da mesma esfera de Poder, afeta negativamente a construção futura e conjunta de novas formas de publicação e comunicação, porquanto cada órgão planeja e executa individualmente tais deveres, com base em métodos, decisões e padrões próprios. Padronizar pode, em muitos casos, significar diminuição do espaço de criatividade, porém aqui seu principal benefício é contribuir para a construção de uma política única de gestão informacional e de governança nos respectivos Poderes, a serem constantemente atualizadas e adequadas às novas tecnologias e demandas informacionais, emanando efeitos imediatos e uniformes sobre todos os portais.

A percepção de tais demandas e dos interesses da sociedade também é outro importante desafio para a efetivação da transparência ativa e da cultura de acesso, a exigir que as informações sejam organizadas e disponibilizadas com vistas a atender precipuamente as demandas do cidadão.

Quando da análise da existência, nos portais, de uma página de perguntas frequentes da sociedade, foi facilmente constatada a dificuldade que alguns órgãos possuem em identificar quais são os questionamentos da coletividade a serem respondidos. A maioria dos portais abordou questões relacionadas ao exercício da atividade jurisdicional, sob o prisma do operador do direito - o que por si reduz a efetividade da informação em relação a coletividade que não se enquadra nesta perspectiva.

Identificar estes interesses, portanto, é um grande desafio ao Poder Judiciário (e aos demais órgãos e entidades do Poder Público), e exige, de forma urgente, a observação conjunta e contínua, com registros sistematizados, sobre as solicitações realizadas com mais frequência pela população perante os órgãos e ouvidorias dos Tribunais. Havendo sucesso em um trabalho 
planejado neste sentido, elevar-se-ia a qualidade das informações dispostas e sua prestabilidade em relação à sociedade, fortalecendo a comunicação e incentivando a cultura de acesso.

Por fim, outro grande desafio identificado, que decorre dos problemas anteriormente apontados (ausência de padrões definidos e percepção dos interesses e demandas da sociedade) é aprimorar a qualidade das informações e a usabilidade dos portais, imprescindíveis para que as informações e serviços prestados pela entidade pública sejam desenvolvidos e mantidos de acordo com as expectativas e necessidades do cidadão, para que este se utilize das informações e serviços de forma plena e satisfatória.

Este desafio, portanto, parte da concepção de que informar é o primeiro passo, mas não o único. Quando o órgão informa de forma ativa, ele deve compreender que não está meramente cumprindo um dever legal, mas também contribuindo para a promoção da cidadania e do Estado Democrático de Direito, e que a satisfação deste objetivo depende (ainda que não somente disso) do modo através do qual se informa e se estabelece a comunicação com o usuário.

Com base nessas considerações e na análise dos portais, percebe-se que a efetivação do controle social, com uma participação popular significativa e democrática, depende do implemento da cultura de acesso com a disponibilização de informações. Para tanto, é necessário que o Poder Público, num sentido amplo, se aproprie e leve em consideração elementos importantes, tais como a uniformização, usabilidade e interoperabilidade, ao utilizar as Tecnologias de Informação e de Comunicação (TIC's) no cumprimento da Lei de Acesso à Informação.É necessário que além de disponibilizar a informação, os órgãos do Poder Judiciário especificamente - ultrapassem a cultura de cumprimento estrito das Resoluções do Conselho Nacional de Justiça e ajam de forma ativa e com antecedência em relação a todos os deveres mínimos estabelecidos pela Lei 12.527/11, ainda que não regulamentados pelo órgão citado. Além disso, é importante que os sites e portais adotem uma sistemática pautada pela uniformização, interoperabilidade e usabilidade, de modo a facilitar o efetivo acesso à informação e o controle social e democrático pelo cidadão.

Conclui-se que apesar das iniciativas existentes com a perspectiva de cumprir as exigências legais, existem desafios à concretização da transparência ativa na Internet, o que exige, sobretudo, o desenvolvimento da cultura de acesso. Nessa perspectiva, é necessário que a disponibilização da informação atenda aos requisitos e elementos constantes na Lei $n^{\circ}$ 12.527/11, com a adoção de mecanismos e ferramentas adequados e eficazes, superando as 
deficiências ora constatadas na pesquisa. Dessa forma, o direito fundamental ao acesso à informação será efetivado, com o consequente fortalecimento da democracia e da participação popular no país.

\section{REFERÊNCIAS}

Acesso à informação e controle social das políticas públicas; coordenado por Guilherme Canela e Solano Nacimento. Brasília, DF: ANDI, ARTIGO 19, 2009.

ARTIGO 19. O direito do público a estar informado. Princípios sobre a legislação de liberdade de informação. Artigo 19: Londres, 1999. O Disponível em:

<http://www.article19.org/data/files/pdfs/standards/public-right-to-know-portuguese.pdf>. Acesso em 09 nov. 2012.

BRASIL. Constituição da República Federativa do Brasil de 1988. Brasília: Senado Federal, 1988. Disponível em: <

<http://www.planalto.gov.br/ccivil_03/constituicao/constitui\%C3\%A7ao.htm>. Acesso em: 08 nov. 2012.

. Conselho Nacional de Justiça. Portal da Transparência. Disponível em: < http://www.portaltransparencia.jus.br/despesas/>. Acesso em 13 nov. 2012.

. Resolução $n^{\circ}$ 70. Dispõe sobre o Planejamento e a Gestão Estratégica no âmbito do Poder Judiciário e dá outras providências. Disponível em: < http://www.cnj.jus.br/gestao-e-planejamento/gestao-e-planejamento-do-judiciario/resolucaon-70 >. Acesso em 08 nov. 2012.

. Resolução $n^{\circ} 79$. Dispõe sobre a transparência na divulgação das atividades do Poder Judiciário brasileiro e dá outras providências. Disponível em: < http://www.cnj.jus.br/atos-administrativos/atos-da-presidencia/323-resolucoes/12197resolucao-no-79-de-9-de-junho-de-2009 >. Acesso em 08 nov. 2012.

Resolução $\mathrm{n}^{\circ}$ 85. Dispõe sobre a Comunicação Social no âmbito do Poder Judiciário. Disponível em: < http://www.cnj.jus.br/atos-administrativos/atos-dapresidencia/323-resolucoes/12200-resolucao-no-85-de-08-de-setembro-de-2009>. Acesso em 12 nov. 2012.

. Resolução $n^{\circ}$ 102. Dispõe sobre a regulamentação da publicação de informações alusivas à gestão orçamentária e financeira, aos quadros de pessoal e respectivas estruturas remuneratórias dos tribunais e conselhos. Disponível em: < http://www.cnj.jus.br/atosadministrativos/atos-da-presidencia/resolucoespresidencia/12218-resolucao-no-102-de-15-dedezembro-de-2009 >. Acesso em 08 nov. 2012. 
. Controladoria-Geral da União. Portal da Transparência. Disponível em:

<http://www.portaldatransparencia.gov.br>. Acesso em 08 nov. 2012.

. Sistema Eletrônico do Serviço de Informação ao Cidadão. Disponível em: <http://www.acessoainformacao.gov.br/sistema/>. Acesso em 08 nov. 2012.

. Comitê Gestor da Internet no Brasil. Dimensões e características da Web brasileira: um estudo do .gov.br. 2010. Disponível em:

<http://www.cgi.br/publicacoes/pesquisas/govbr/cgibr-nicbr-censoweb-govbr-2010.pdf>. Acesso em 09 nov. 2012.

. Neutralidade na Rede: Internet para todos. Revista .br, Ano 03, edição 04, 2011. Disponível em: <http://www.cgi.br/publicacoes/revista/edicao04/cgibr-revistabred4.pdf>. Acesso em: 09 nov. 2012.

. Lei $\mathrm{n}^{\circ} 12.527$, de 18 de novembro de 2011. Regula o acesso a informações previsto no inciso XXXIII do art. 5o, no inciso II do § 30 do art. 37 e no § 20 do art. 216 da Constituição Federal; altera a Lei no 8.112, de 11 de dezembro de 1990; revoga a Lei no 11.111, de 5 de maio de 2005, e dispositivos da Lei no 8.159, de 8 de janeiro de 1991; e dá outras providências. Disponível em: <http://www.planalto.gov.br/ccivil_03/_ato2011-2014/2011/lei//12527.htm>. Acesso em 08 nov. 2012.

. Ministério do Planejamento, Orçamento e Gestão, Governo Eletrônico. E-PWG Padrões Web em governo Eletrônico. Disponível em < https: //www.governoeletronico.gov.br/acoes-e-projetos/padroes-brasil-e-gov> . Acesso em 13 nov 2012.

- Ministério do Planejamento, Orçamento e Gestão, Secretaria de Logística e Tecnologia da Informação. Padrões Web em Governo Eletrônico: Cartilha de Usabilidade. Brasília: MP, SLTI, 2010, p.6-7. Disponível em: <http://www.governoeletronico.gov.br/acoes-eprojetos/padroes-brasil-e-gov>. Acesso em 15 nov. 2012.

Portaria Interministerial $n^{\circ}$ 140, de 16 de março de 2006. Disciplina a divulgação de dados e informações pelos órgãos e entidades da Administração Pública Federal, por meio da rede mundial de computadores - internet, e dá outras providências. Disponível em: < http: / / www.cgu.gov.br/Legislacao/Arquivos/Portarias/Portaria_Interministerial.pdf>. Acesso em: 25 jul. 2012.

. Tribunal Regional Federal da $1^{\text {a }}$ Região. Página inicial. Disponível em: <www.trf1.jus.br>. Acesso em 07 nov. 2012;

. Tribunal Regional Federal da $2^{\text {a }}$ Região. Página inicial. Disponível em: <www.trf2.jus.br>. Acesso em 07 nov. 2012;

Atendimento ao cidadão. Disponível em: <

http://www.trf2.jus.br/atendimento/atendimento/atendimento2.aspx?menu=Acesso\%20\%C3\%A0 \%20Informa\%C3\%A7\%C3\%A30>. Acesso em 07 nov.2012

REDESG / Revista Direitos Emergentes na Sociedade Global - www.ufsm.br/redesg v. 1, n. 2, jul.dez/2012 ReVISTA do Programa de Pós-graduaÇÃo EM DiReito da Universidade FEderal de SANTA MARIA - www.ufsm.br/ppgd 
Perguntas Frequentes. Disponível em <

http://www.trf2.jus.br/Paginas/perguntas_frequentes.aspx?menu=Acesso\%20\%C3\%A0\%20Informa \%C3\%A7\%C3\%A3o >. Acesso em 08 nov. 2012.

Ouvidoria Geral da Justiça Federal da $2^{\text {a }}$ Região. Disponível em: < http://www.trf2.jus.br/ouvidoria/default.aspx >. Acesso em 08 nov. 2012.

. Tribunal Regional Federal da $3^{\text {a }}$ Região. Página inicial. Disponível em: <www.trf3.jus.br>. Acesso em 07 nov. 2012;

. Tribunal Regional Federal da $4^{\text {a }}$ Região. Página inicial. Disponível em: <www.trf4.jus.br>. Acesso em 07 nov.2012;

. Perguntas frequentes. Disponível em: <

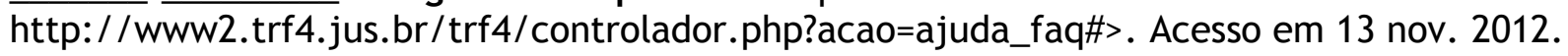

. Tribunal Regional Federal da $5^{a}$ Região. Página inicial. Disponível em: <

www.trf5.jus.br>. Acesso em 07 nov.2012

Cidadania e redes digitais = Citizenship and digital networks. /Sergio Amadeu da Silveira, organizador. - 1a ed. - São Paulo: Comitê Gestor da Internet no Brasil : Maracá - Educação e Tecnologias, 2010. Vários tradutores.

FREITAS, Cinthia Obladen de Almendra (Org.). Direito e Questões Tecnológicas: aplicados no desenvolvimento social. Curitiba: Juruá, 2008.

GONÇALVES, Maria Eduarda. Direito da Informação: novos direitos e formas de regulação na Sociedade da Informação. Almedina: Coimbra, 2003.

Governança de TI: transformando a Administração Pública no Brasil/ organizadores: Marco Cepik e Diego Rafael Canabarro. Porto Alegre: WS Editor, 2010.

INTERNACIONAL CONFERENCE ON THE RIGHT PUBLIC INFORMATION. February, 27-29, 2008. Declaração de Atlanta e plano de ação para o avanço do direito de acesso à informação. Disponível em:

<http://www.cartercenter.org/resources/pdfs/peace/americas/atlanta_declaration_unofficial_ portuguese.pdf>. Acesso em 08 nov. 2012.

INTERNACIONAL. Parceria para o Governo Aberto. Declaração de Governo Aberto. Disponível em:

<http://www.opengovpartnership.org/sites/www.opengovpartnership.org/files/page_files/Decl aracao_de_Governo_Aberto.pdf>. Acesso em 08 nov. 2012.

Internet e participação política no Brasil. Orgs. Rousiley Celi Moreira Maria, Wilson Gomes, Francisco Paulo Jamil Almeida Marques. Poro Alegre; Sulina, 2011.

MAGALHÃES, Darcilene Maria Barbosa. A Aplicação das Tecnologias da Informação e da Comunicação - TICs, na Gestão Pública: um estudo sobre o governo eletrônico por meio dos

REDESG / Revista Direitos Emergentes na Sociedade Global - www.ufsm.br/redesg v. 1, n. 2, jul.dez/2012 ReVISTA do Programa de Pós-graduação em DiReito da Universidade Federal de SANTA MARIA - www.ufsm.br/ppgd 
sítios (websites) oficiais dos Estados do Brasil. Belo Horizonte: 2008, p.31. Disponível em: < http://bdtd.ibict.br/>. Acesso em 13 nov. 2012.

MARTINS, Paula Lígia. Acesso à informação: Um direito fundamental e instrumental. Acervo: Rio de Janeiro, 2011.

MENDEL, Toby. Liberdade de informação: um estudo de direito comparado. 2.ed. Brasilia: UNESCO, 2009.

MIRAGEM, Bruno. A Nova Administração Pública e o Direito Administrativo. São Paulo: Editora Revista dos Tribunais, 2011.

PIANA, Ricardo Sebastián. Gobierno elecrónico: gobierno, tecnologias y reformas. $1^{\text {a }}$ ed. La Plata: Univ. Nacional de La Plata, 2007.

PINHEIRO, Patrícia Peck. Direito Digital. 4 ed. rev., atual. e ampl. São Paulo: Saraiva, 2010. PINHO, José Antônio Gomes de. Investigando portais de governo eletrônico de estados no Brasil: muita tecnologia, pouca democracia. Rio de Janeiro: Revista de Administração Pública, v. 42, n. 3, mai-jun. 2008.

SIRAQUE, Vanderlei. Controle social da função administrativa do Estado: possibilidades e limites da Constituição Federal de 1988. 2 ed. São Paulo: Saraiva, 2009.

Recebido em: 28.11.2012

Aprovado em: 26.02.2013 